\title{
Body size and reproductive parameters in the wild boar Sus scrofa
}

\author{
Pedro FERNÁNDEZ-LLARIO and Patricio MATEOS-QUESADA
}

\begin{abstract}
Fernández-Llario P. and Mateos-Quesada P. 1998. Body size and reproductive parameters in the wild boar Sus scrofa. Acta Theriologica 43: 439-444.

Parameters involved in the reproductive performance of wild boar Sus scrofa Linnaeus, 1758, such as fertility rates and litter size, show considerable intrapopulational variability. In this work we analyze a total of 198 females, culled by hunting in the Villuercas region (Cáceres, Spain), in an area with food suplementary throughout the year. The $31 \%$ of the total number of females examined, and the $47 \%$ of the female above $44 \mathrm{~kg}$ body weight, were in breeding condition (either gestating or lactating). There were no differences among four central months throughout the breeding period in the proportion of breeding females. Mean litter size was positively influenced by physical features of the female such as body size and weight. The month of the year (within the central breeding period) did not affect litter size. These findings indicate that reproductive decisions of females, ie whether or not to start gestation and the number of offspring in the litter, are mainly determined by their physical features.

Cátedra de Biología y Etología, Facultad de Veterinaria, Universidad de Extremadura, 10.071 Cáceres, Spain, e-mail: pfernandez@ctv.es
\end{abstract}

Key words: Sus scrofa, reproduction, fertility, litter size, Villuercas, Mediterranean

\section{Introduction}

The wild boar Sus scrofa Linnaeus, 1758 is at the moment the most widely distributed ungulate in the Iberian penninsula having expanded the areas which it occupies as well as increasing its numbers in those areas where it already lived (Sáez-Royuela and Tellería 1986). Knowledge of the reproductive characteristics of the population present in the Iberian penninsula has given an explanation for this present situation, the studies by Vericad (1983), Sáez-Royuela (1987) or Abaigar (1990) being outstanding. The study of the different populations has also discovered differences in the reproductive characteristics such as fertility of the females or size of the litter.

These two aspects of the reproductive biology of the wild boar are, apparently, conditioned to a great degree by the physical characteristics of the female (Sáez-Royuela 1987, Abaigar 1990), although there are also other factors to be taken into account such as density of population (Aumaitre et al. 1982), the periods of light (photo-periods) (Mauget et al. 1980) or the quantity and moment of available food (Aumaitre et al. 1982). 
The aim of the present paper is to analyse the influence of certain physical parameters (weight, physical condition, total length, height and body length ) and seasonality (in the four months where there are hunts which we can consider as the central reproductive months) of the wild boar.

\section{Study area}

The study was made in the Villuercas region, in the centre-west of the Iberian penninsula. The wild boar came from several estates of a total extension of about 3500 hectares, mostly devoted to game hunting. As well as wild boar, and only referring to ungulates, there is a large population of red deer Cervus elaphus, roe deer Capreolus capreolus and in recent years fallow deer Dama dama have also been introduced.

The local vegetation is abundant mediterranean forest composed principally of holm oak Quercus ilex, cork trees Quercus suber and oak Quercus pyrenaica, which together make up for $80 \%$ of the area under study. There are also pine forests Pinus halepensis, and also about 100 hectares of chestnut trees Castanea sativa which are grown for their nuts. Between the months of February and October, and very specially during the summer months, a food supplement is provided of about 15000 kilogrammes of fruit and corn.

\section{Material and methods}

Totally, 198 females from the hunts were examined, being this hunting activity a widely used way of obtaining data in the areas where the wild boar is commonly hunted (Galliard et al. 1987, Sáez-Royuela and Tellera 1988, Abaigar 1990, Badia et al. 1991). Data were collected during the hunting seasons of 1994-1995, 1995-1996 and 1996-1997. Due to the fact that the wild boar analyzed were dead animals from hunting they reflect the situation between the months of October and February (the official hunting season), both inclusive.

The following data were taken from the females: date of death, reproductive state, weight, total length, height, body length. In the case of pregnant females, the weight considered was that of the mother subtracting the weight of the unborn foetuses it carried. With reference to the reproductive state, all of the females were included in one of these two categories: in reproduction, without reproduction. Refering to the first group, two more types were defined: pregnant females carring foetuses, and female with milk in their mammary glands. When comparisons were made this was only between females which had mostly or completely finished their development, we have taken into account females weighing 45 kilogrammes or more, this being the accepted weight of several authors (see Sáez-Royuela 1987, Spitz et al. 1990). Physical condition was also calculated using a relationship between logarithm of length, in our case height, and logarithm of weight, being the physical condition the residual values of this relation (Andersson 1992). The number of embryos or foetuses in pregnant females was also registered.

The age of the foetuses (t) was determined using the Huggett and Widdas formula (1951), which had already been applied to the wild boar (Vericad 1983),

$$
\mathrm{t}=\frac{\sqrt[3]{\mathrm{Pm}}}{0.097}+24.1
$$

where $\mathrm{Pm}$ is the average weight of the foetus of the litter.

The statistics employed are parametrical since in all the variables the Kolomogorov-Smirnov Normality Test has been applied, with the result $p>0.05$ in all cases. 


\section{Results}

Of 198 females analysed, $137(69.2 \%)$ were not in reproduction, and $61(30.8 \%)$ were in reproduction, of which 52 were pregnant and 9 were lactating. Those in reproduction had the greatest weight (ANOVA $F=33.84$, $\mathrm{df}=1,195, p<0.001$ ), as well as a greater total length (ANOVA $F=28.69$, $\mathrm{df}=1,195, p<0.001$ ) and height (ANOVA $F=27.13, \mathrm{df}=1,195, p<0.001$ ). There were no differences in the length of tarsus (ANOVA $F=3.60, \mathrm{df}=1,195, p=0.06$ ) nor in physical condition (ANOVA $F=0.99$, $\mathrm{df}=1,195, p=0.321$ ).

To determine the influence of weight on reproductive state, the females were placed in 6 size groups. The results indicate (Fig. 1) that the percentage of reproductive females was low among small females and high among large females $\left(\chi^{2}=25.85\right.$, df $\left.10, p=0.004\right)$.

On the other hand, there were no differences $\left(\chi^{2}=0.56, \mathrm{df}=1, p=0.450\right)$ in the percentage of females in reproduction in the two seasons studied, winter $(33.4 \%)$ and autumn $(28.5 \%)$. The result was the same $\left(\chi^{2}=0.474, \mathrm{df}=1, p=0.493\right)$ when only adult growing females $(34-44 \mathrm{~kg}$ ) were analysed, although the percentage of pregnant females in autumn $(24.3 \%)$ was slightly greater than in winter $(18.2 \%)$.

The months when most of the females got pregnant was in August (43\%) and September (31\%) (Fig. 2), although there were conceptions from June to October. The months when most of the births took place were in December $(42 \%)$ and January (35\%).

The size of the litter was $3.58 \pm 1.33$ (average \pm standard deviation) and varied between 1 and 7 (Fig. 3). No differences were observed during the seasons analysed (ANOVA $F=0.07, \mathrm{df}=1,63, p=0.793$ ), neither were there any differences between years (ANOVA $F=0.058, \mathrm{df}=2,59, p=0.994$ ). Litter size correlated positively with several body measurements: weight $(r=0.392, p=0.001)$, total length $(r=$ $0.33, p=0.008)$, and height $(r=0.267, p=0.033)$, while no correlations physical condition $(r=0.108, p=0.3940)$ and tarsus $(r=0.011, p=0.933)$.

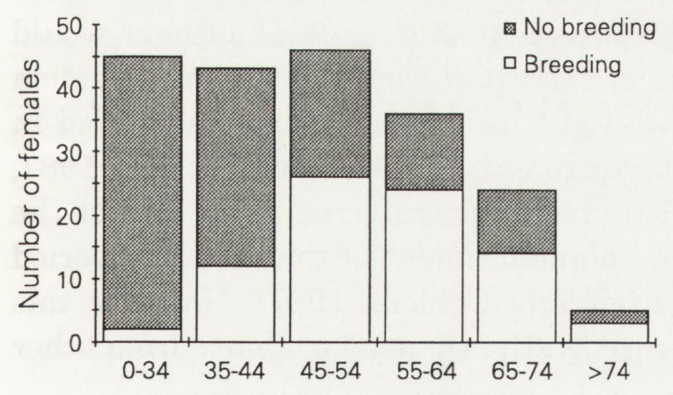

Female body weight $(\mathrm{kg})$
Fig. 1. Relationship between female body weight and breeding condition. 


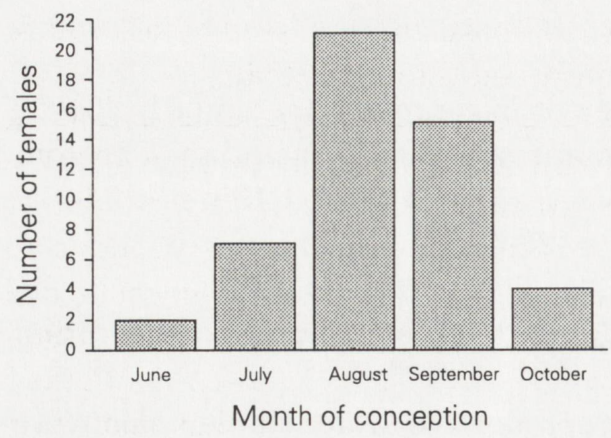

Fig. 2. Monthly frequency of conceptions, estimated on the basis of litter weights from females culled between October and January.

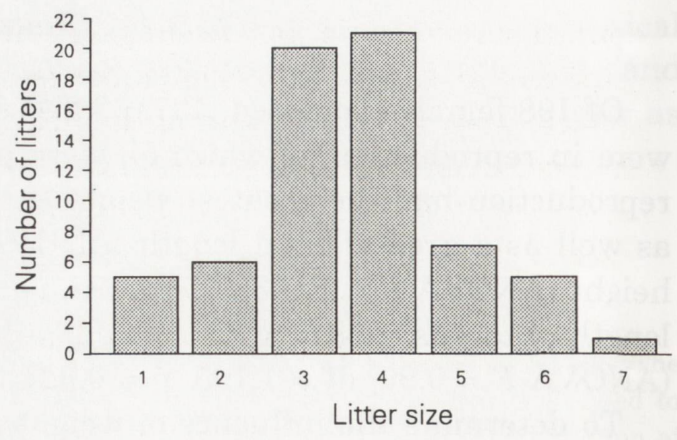

Fig. 3. The distribution of litter size.

\section{Discussion}

The population of wild boar studied is not different from that of other studies (see Mauget and Pépin 1987 or Sáez-Royuela 1987) with respect to physical characteristics of breeding females and their reproductive phenology. Because breeding females are larger than non-breeding ones, this presumably indicates that the amount of resources available for reproduction increases once body development has reached its peak (Tuomi 1980, Gerard et al. 1991, Ahmad et al. 1995). The proportion of breeding females is about the same in autumn and winter, and gestation frequency is highest in the winter (Abaigar 1990). This fact, which is due to the advanced period of conception of the wild boar in our study (mainly in August and September), differs from earlier studies in other parts of Europe (Aumaitre et al. 1982, Mauget et al. 1984) or even in other parts of the Iberian penninsula (Sáez-Royuela 1987, Abaigar 1990, Fernández-Llario 1996) where the maximum number of conceptions takes place in November or December.

We believe that this behaviour could be due to the large amounts of food which is supplied artificially during the summer and which enables the females to reach the necessary physical requirements, which control the beginning at the reproductive cycle (Massei et al. 1996). The advancement of the period of heat would be, then, a direct consequence of this type of care, and would lead us to question the accepted idea the periods of increasing light have an implicit rest period in wild boar reproduction (Mauget 1980, Aumaitre et al. 1982, Sáez-Royuela 1987, Abaigar 1990, Fernández-Llario 1996). This has been referred to as one of the most important determining factors in the commencement of the breeding period in the wild boar (Ahmad et al. 1995, Barber and Coblenz 1987). However this subject must be studied in greater depth specifically, we need evidence from other 
populations with similar feeding conditions to those in this study and where gestations in August and September is not observed (Mauget 1980).

With reference to the size of the litter, 3.58 piglets per female is lower than in other penninsular populations, such as 4.04 in Doñana (Fernández Llario 1996), 4.2 for the wild boar in the province of Burgos (northern Spain) (Sáez-Royuela 1987), and 4.1 in Almería (east of Spain) (Abaigar 1990). The values obtained in more distant places are even larger, eg France 4.44 (Dardaillon 1988) and 4.75 (Aumaitre et al. 1982), Italy with values between 2.8 and 4.5 (Massei et al. 1996), Germany with more than 5 (Stubbe and Stubbe 1977) or 5.2 piglets in Poland (Dzięciołowski 1991). This divergence could, in part, be due to Bergmanns rule (see Vericad 1983, Sáez-Royuela 1987); that is the more northern populations, tend to have an increased size of litter (Stearns 1992). The rule has been also confirmed for other species of mammals (Cockburn et al. 1983, Conway et al. 1974, Fleming and Rauscher 1978).

This litter size could also be a result of heavy hunting activity within the area. Therefore, in this type of peninsular zone the mean age of the population, and as such of the females, is quite low (Sáez-Royuela 1987). This in turn leads to a large part of the reproducing females being very young, which contributes to the fact that the litter sizes are low (Sáez-Royuela 1987, Dzięciołowski et al. 1992, Ahmad et al. 1995).

Finally, one must also take in account the possible influence that the way food is supplied could have. The fact that it is administered in very specific areas leads to very high population densities at conception, and this in another condition which could contribute to lower litter sizes (Dawkins 1980, Massei et al. 1996).

Acknowledgements: I would like to thank A. García and S. Mateos for their help in the collection of data in the hunts. And also Dr J. Carranza for supplying ideas and correcting the manuscript.

\section{References}

Abaigar T. 1990. Características biológicas y ecológicas de una población de jabalíes (Sus scrofa L.) en el SE Ibérico. M Sc thesis, University of Navarra, Pamplona: 1-360.

Ahmad E., Brooks J. E., Hussain I. and Khan M. H. 1995. Reproduction in Eurasian wild boar in central Punjab, Pakistan. Acta Theriologica 40: 163-173.

Andersson S. 1992. Female preference for long tails in lekking Jackson's widowbirds: experimental evidence. Animal Behaviour 43: 379-388.

Aumaitre A., Morvan C., Quere J. P., Peiniau J. and Valet G. 1982. Productivité potentielle et reproduction hivernale chez la laie (Sus scrofa scrofa) en milieu sauvege. Journées Recherche Porcine en France 14: 109-124.

Badia J., Spitz F. and Valet G. 1991. Estimate of the size of a hunted population. Ecological Modelling 55: 113-122.

Barber D. W. and Coblenz B. E. 1987. Diet, nutrition and conception in feral pigs on Santa Catalina Island. The Journal of Wildlife Management 51: 306-317.

Cockburn A., Lee A. K. and Martin R. W. 1983. Macrogeographic variation in litter size in Antechinus (Marsupalia: Dasyuridae). Evolution 37: 86-95. 
Conaway C. H., Sadler K. C. and Hazelwood D. H. 1974. Geographic variation in litter size and onset of breeding in cottontails. The Journal of Wildlife Management 38: 473-481.

Dardaillon M. 1988. Wild boar groupings and their seasonal changes in the Camargue, southern France. Zeitschrift für Säugetierkunde 53: 22-30.

Dawkins M. S. 1980. Animal Suffering: The Science of Animal Welfare. Chapman and Hall, New York: 1-149.

Dzięciołowski R. M. 1991. Ecological niches of five big ungulate in a forest tract. Folia Forestalia Polonica, Series A-Forestry 33: 56-70.

Dzięciołowski R. M., Clarke C. M. H. and Frampton C. M. 1992. Reproductive characteristics of feral pigs in New Zealand. Acta Theriologica 37: 259-270.

Fernández-Llario P. 1996. Ecología del jabalí en Doñana: Parámetros reproductivos e impacto ambiental. M Sc thesis, University of Extremadura, Cáceres: 1-205.

Fleming T. H. and Rauscher R. J. 1978. On the evolution of litter size in Peromyscus leucopus. Evolution 32: 45-55.

Gaillard J. M., Vassant J. and Klein F. 1987. Quelques caractéristiques de la dynamique des populations de Sanglier (Sus scrofa scrofa) en milieu chassé. Gibier Faune Sauvage 4: 31-47.

Gerard J. F., Teillaud P., Spitz F., Mauget R. and Campan R. 1991. Le Sanglier. Revue d'Ecologie (Terre Vie), Suppl. 6: 1-55.

Huggett A. and Widdas W. F. 1951. The relationship between mammalian foetal weight and conception age. Journal of Physiology 114: 306-317.

Massei G., Genov P. V. and Staines B. W. 1996. Diet, food availability and reproduction of wild boar in a Mediterranean coastal area. Acta Theriologica 41: 307-320.

Mauget R. 1980. Régulations écologiques, comportementales et physiologiques (fonction de reproduction), de l'adaptation du sanglier, Sus scrofa L., au milieu. M Sc thesis, University Francois Rabelais, Tours: $1-380$.

Mauget R. and Pepin D. 1987. Energy intake, growth and timing of puberty in the European Wild Boar (Sus scrofa L.). Abstracts of the XVIIIth Congress of the International Union of Game Biologists, Kraków, Poland, August 1987: 119.

Mauget R., Campan R., Spitz F., Dardaillon M., Janeau G. and Pepin D. 1984. Synthse des connaissances actuelles sur la biologie du sanglier, perspectives de recherche. Symposium International sur le sanglier, Toulouse, France, INRA: 15-50.

Sáez Royuela C. 1987. Biología y ecología del jabalí. M Sc thesis, Complutense University, Madrid: $1-234$.

Sáez-Royuela C. and Tellería J. L. 1986. The increased population of wild boar (Sus scrofa L.) in Europe. Mammal Review 16: 97-101.

Sáez-Royuela C. and Tellería J. L. 1988. Las batidas como método de censo en especies de caza mayor: aplicación al caso del jabalí (Sus scrofa L.) en la provincia de Burgos (norte de España). Doñana, Acta Vertebrata 15: 215-223.

Spitz F., Gleize J. C. and Duncan P. 1990. Particularités de la croissance pondérale du sanglier: cas des populations de Camargue (sud de la France). Mammalia 54: 405-414.

Stearns S. C. 1992. The evolution of Life Histories. Oxford University Press: 1-249.

Stubbe W. and Stubbe M. 1977. Vergleichende Beiträge zur Reproduktions - und Geburtsbiologie von Wild - und Hausschwein Sus scrofa L., 1758. Beiträge zur Jadg- und Wildforschung 10: 153-179.

Tuomi J. 1980. Mammalian reproductive strategies: a generalized relation of litter size to body. Oecologia 45: 39-44.

Vericad J. R. 1983. Estimación de la edad fetal y períodos de concepción y parto del jabalí (Sus scrofa L.) en los pirineos occidentales. XV Congreso Internacional Fauna Cinegética y Silvestre, 1981, Trujillo: 811-820.

Received 26 September 1997, accepted 2 June 1998. 